\title{
BRIDGING CRITICAL DISCOURSE ANALYSIS IN MEDIA DISCOURSE STUDIES
}

\author{
Ratna Sari \\ Department of English Education, Faculty of Teacher Training and Education \\ Universitas Lancang Kuning, Pekanbaru, Indonesia \\ E-mail: ratnasarimarlis@gmail.com \\ Silvia Eka Putri \\ Department of English Education, Faculty of Teacher Training and Education \\ Universitas Lancang Kuning, Pekanbaru, Indonesia \\ E-mail: silviaeputri@gmail.com \\ Herdi \\ Department of English Education, Faculty of Teacher Training and Education \\ Universitas Lancang Kuning, Pekanbaru, Indonesia \\ E-mail: herdi@unilak.ac.id \\ Budianto Hamuddin \\ Department of English Education, Faculty of Teacher Training and Education \\ Universitas Lancang Kuning, Pekanbaru, Indonesia \\ E-mail: budihamuddin@unilak.ac.id
}

\begin{abstract}
APA Citation: Sari, R., Putri, S. E., Herdi, H., \& Hamuddin, B. (2018). Bridging critical discourse analysis in media discourse studies. Indonesian EFL Journal, 4(2), 80-89. doi: 10.25134/ieflj.v4i2.1379.
\end{abstract}

\begin{abstract}
The precarious and critical period of the initiation of Discourse Analysis was populer at the end of the 1990s and the beginning of 2000s. Various approaches and frameworks were proposed during the time especially in the field of Applied Linguistics. This is including Critical Discourse Analysis (CDA) as one of its leading areas. This present study aimed at exploring and catching out how the CDA' presentation in overall related to Media studies and how it can be applicable to uncover an unseen ideologies while examining the existence of media discourse studies. The study is considering 25 journal studies to scrutinize the ways and methods used in discern social phenomena while illuminating the true characteristics of the social actors. As result, it was revealed that CDA is used openly to expose ideologies that somehow differentiate oppressed groups by offering a dummy image used by the highest authority or elite.

Keywords: CDA; ideology; media discourse; social actors; power.
\end{abstract}

\section{INTRODUCTION}

The analysis of language in use we might call discourse analysis (DA) is the way of accepting interactions in social areas including written and spoken discourse. In the other word, It tries to recognize the various part in linguistics used among social context, identities, and relation. It can be useful to any problem and condition. To be sure of definitions this study seesdiscourse analysis is a way of thinking or approaching a problem. It means that DA ussed as an approach to help us to understand the situation in a particular discourse phenomenan and find the resolution. It is also, a way for analyzing the relation among content, ideas, and structure of the text encode it among the ideas itself. The definition above well recognised, "DA provides a basic methodology to describes and analyze how the structure and content of the text. encodes ideas and the relation among the ideas itself that are present in the text, systematically" (Hamuddin, 2012). 
Since the 1990s, CDA recognized as one of the most dominant research in discourse area as well as communication. A mammoth alike papers have been published in the area of CDA and among it well known resercher are Teun van Dijk, Ruth Wodak, and Norman Fairclough. They have donated to this field through their influential work. These researchers put various approaches and theories with their different frameworks and method of discourse analysis.

Van Dijk (1990) study "Society and Discourse" as his first well-known journal that discussed around the globe and then followed by several of his books. it is discussed how and why discourse contributes to the text by re-production of structures, cultural and ideological. Critical discourse has various uses of language of power in society. Therefore, this study saw that van Dijk through his "Society and Discourse" leaves us with an important view to examine the enactment of power and to understand the means by which power exercised by the domination group or elite upon the marginalized as well as those who were oppressed.

Among Ruth Wodak academic works "Methods of Critical Discourse Analysis" is one of her phenomena. This book explains the introduction of CDA and gives an overview of the various CDA theories and methods associated with this sociolinguistic approach. It also explained the leading figures in CDA and the methods to which they are related. The book aimed to provide a deep and comprehensive description of the methods, an exploring of the theories to which methods refer and a comparative treatment of each of these methods so that students may be able to determine which is the most suitable or appropriate to select to help in answering their research question. This book also quiet balance between theory and its application in the fields of linguistics, sociology, social sciences and social psychology in general.

Moreover, through Norman Fairclough "Discourse and Social Change" CDA well known introduce 1993. He tries to build an understanding and links on a critical introduction to discourse analysis as it is practiced in a variety of different disciplines at that time, from linguistics, sociolinguistics to sociology and cultural studies. Fairclough shows his concerns with the analysis of discourse can be combined with others approach, in a systematic and productive way, with an interest in broader problems of social analysis and social change

These three scholars seem to share the same perspective on what is the principles of CDA

- CDA investigated people's domination that experienced injustice.

- CDA contains various theories, methods, and application of issues in society.

- CDA discussed social problems such as human rights, social discrimination, mishandling various power in Indonesia such as racism, prejudice, and so on.

- CDA does not the emphasis on a particular discipline and it is openly presented in public.

- CDA explain the phenomena that happened in the society

Moreover, they also explained in their next works that $\mathrm{CDA}^{\prime}$ application is not refined for text analysis (Van Dijk, 2009) but consists of several methods (Wodak \& Meyer, 2009). It is to analyzing 'social phenomena that are definitely complex (Wodak \& Meyer, 2009). Van Dijk (2003) recommends that CDA depends on how strength, dominance, and inequality are practiced in politic and social contexts. In bright of this approach, Fairclough (1995) suggests CDA is the connection between a) event and texts b) broader social and cultural relationships" (p. 132) moreover Van Dijk (2003) also underlined CDA depends on how the social image by social groups.

Therefore this study considers CDA as the correlation in 'discourse, social and cultural development' that emphases on "typical social problems and political issues (i.e. power, dominance, interests hegemony, class, gender, race, reproduction, gender, institutions, discrimination, social structure, ideology and social order)". Nevertheless, CDA exploring and focuses on the structure of discourse by reproducing and challenging relationships between dominance power in a society. As this study would like to underline 
that CDA services to see many unseen of ideologies and media' power in discourse studies by implementingCDA and its application theories and frameworks in the related studies.

Media discourse is a fascinating view to exploring, mostly when objectivity grows into the main topic. As Hamuddin (2012) mentions in his paper "we should also concern regarding media discourse is access". It means that social people more or less linked the power of force limitations on media' access. In another argument, Van Dijk also said the "influential people can make affect the structure of language in society". As well as, Media as power and encouragement to the shaping of media users' critical thinking.

The fact that media discourse is public incomes of many conversation analysis that is involved in its form of influential talk, which can be related to different forms of talk. as we know that, an Improvements in technology have great balance to use in media discourse. Also, it can be increased because of its availability on newspapers, radio and television programs and etc. This study would offerings the differences between CDA approaches and theories as said by Van Dijk, Ruth Wodak, and Norman Fairclough to make this study crystal clear on the methods. The works below gifts the several models of social theories that used in the various ideological thinking.

\section{Wodak's historical-discoursemethod}

Ruth Wodak is one of a legendary icon in CDA, who has offered various studies on discourses related to prejudice, racism, discrimination etc. in society. Wodak in The historical-discourse analysis conducted a study on the anti-Semitism discourses in 1990, and which role's emphasis in the historical area.Within CDA, the media is realized as public space and discourse of media as the strategic location and social struggle. Written discourse is most prominent in the CDA on media studies so far. Although, media text has gained a lot of attention that has been shared by radio and television. "if various disciplinary sides are not we analyzed, and their epistemological frame not we reflected before used or integrated, and then interdisciplinary does not have much sense" (Wodak, 2003).

Nonetheless, she offered defined criteria for an interdisciplinary methodology in a concept of; common understanding of analytical concepts (Wodak, 2003). There is critical of social study such as CDA.Wodak presented three types of critique in DiscourseHistorical Method which release rationalization on why certain analysis once it has criticized, seems valid and abstract (Reisigl and Wodak, 2009). There are three types of analysis:

1. Socio-analysis aims to draw on their background knowledge to understanding discursive events.

2. Analysis of text aims to discover any conflicts, self-contradictions, paradoxes, and quandaries in internal discourse structures.

3. Future-prospective tries to find the improvement of communication

Further in this research' approaches is investigated discourse by genre of text are supposed to be interconnected (Reisigl \& Wodak, 2009) Texts are deliberated in part of discourse as bridges between ideological and discourse structures. It is observed that discourse is not a closed unit of speech but it is the unit which is open to multiple analyses and connection. Then, it can be brought up to be genre and it is recognized through the manipulation of discourse for a particular purpose. Also, discourse used in a phenomenon of social is realized through different genres, for instance, by debate in politics, public speech, news reports, at the public conference.

The basic power of Wodak's work is the relationship between intertextual and interdiscursivity discourse. Intertextual focuses on how texts are connected to other texts or discourse pointedly to one another in past and present events. It is also related to interdiscursivity as all the communicative actions which occur to earlier events. Meanwhile, it explores how discourses are associated with one another in multiple ways and how it consequently relates to another 
form of discourse. Additionally, interdiscursivity is a combination of discourses and genres in a communicative purpose.

Supremely, in DHA' analysis follows the three-step critical procedure in which a) the subject of specific discourse is identified, b) discursive strategies are investigated, c) the particular context of linguistic comprehensions is examined. The following questions are used in DHA analysis: What characteristics, qualities, and features are recognized to social actors, objects,phenomena/events, and processes?

- From what perspective are these selections, attributions and opinions expressed?

- How are persons, objects, phenomena/events, processes, and actions?

- What arguments are engaged in discourse' question?

- Are the personal statements spoken overtly; are they increased or decreased?

Finally, The strength of Wodak's methodology in DHA is analytical concepts are direct and understandable to the person who is experienced in the field of linguistics but it may be determined for others with nonlinguistic knowledgeThe insufficiency of this method liesmerely on its framework as it is hugely designed and it can be fundamental to interpret theconcept or analysis .

\section{Van Dijk's ideology and social theories}

He studied Ideology' theory is the essential framework for establishing compound ideological theories and consumptions. It controls the judgments by a social group which then represent social characteristics from the group, is based on identities, goals, norms, values, positions, and resources of them. For example, feminists share ideas such as abortion, optimistic actions and stereotypes by males. Hence, these ideologies lead to feminist. It is supposed by members group of society through long-term progressing. It is associated with positive and bad properties. Cognitive gatherings are the basic method which organizes, display and control outlooks from the social group. Every ideological given experience of someone who is mentioned as models. Van Dijk asserted models are specific information about actions managed the shortterm memorial. In other words, models are matching to cognitive functions as the thinking and knowledge of an individual. It is the capability to control proficiencies by the social actor. Related to this, models control the various acts of human habitual life as an ideology. The line here brings the existence of Van Dijk's ideological square. Van Dijk (2000) framed values for expressing ideological analysis by different ideological stances. There are: Positive things Emphasis and Negative things Emphasis

These points show the wider contextual strategy of positive or negative presentation. Self-presentation argues the individual's action as a group of participants by asserting different ideological notions with positive behavior. This is conflicts characteristic as the communication form faces the other people. So, there are positive or negative stances in context of especially in studies of media discourse.

Further, Van Dijk (2009) tries to link cognitive approaches. Nevertheless, CDA attack to the expectations made by the more powerful on the less powerful. He announced CDA as the critical perception, situation or attitude in social practice. Because of its reason, he offered the discourse, cognitive and society. These emphasize of the ways of discourse structure in social discrimination, dominion, and ideologies occur. So, to discover social actors we need a connection, it should look at the structure of discourse and society. He also shows out the white group are control leads to social discrimination and racism in certain countries. Similarly, CDA is concentrated on discrimination in society.

\section{Fairclough social theories}

This review was conveyed by Fairclough (1992) studied discourse of social theory aims to analyze the political and social event. Deceptively, these indications show various world sights from different perspectives. He stated that "a language is social practice' form rather than an individual activity". This insight is interrelated to power and also the ideology in discourse. A social group that follows political or economic activity with 
propositions contain to their social power.In discourse, he proposed 3 principles of social practice. Firstly, Practice in society is thinking the process of social structures. He stated in his study discourse aims to study the written features to know "how is the text designed, why it is designed in this way, and how else could it have been designed?" (Fairclough, 1995 , p. 202). Then, exploration of text describes on the formal features like a phrase, sentence vocabulary, grammar, syntax, images, figures, color, or a blend all of the media. Secondly, paradigms of personalities between various classes in society which involves the consumption, production, distribution of texts by how writers processing to produce texts, and readers understanding. Thirdly, social practice includes background knowledge of a language such as functions of identity and relational. Furthermore, it is the connection between social structure, practice, occasion, and semiotics. Overall, social theory is about how discourse in society on the interaction outlines between participants, goals, and types of social events.

Matched with this theory, $\mathrm{He}$ has framed CDA which contains text, discursive and social practice. These frameworks explain the certain occurrence and highlight of discourse. Commonly, it is aimed at presenting ideologies which are challenging when the text is interrelated to the social context. The first of dimensional framework is the occurrence of makes a possible textual linguistic analyze features. Hence, Fairclough also organized linguistic features into four main classifications which are vocabulary, cohesion, grammar in the text structure (Fairclough, 1992; Jorgensen and Phillips, 2002). It means that by these linguistic features the correlation society and text. It is also linked to the conversational practice which texts are typically inspired differently depends on social context. An example which can be applicable to the pattern of CDA. Such as the production, distribution, and taking theinformation from the text. So, we need to practice in our society by seeing who are our goal, type of person, and events which are related to our reader understanding from our text analyze.

\section{METHOD}

In showing the review, first, the electronic' search was effected in from Google Scholar database. Google Scholar was used because it is free to access and it keys literature of disciplines. In choosing related studies for the review, the search was limited to, a period of ten years since 2005 to 2015 . Keywords such as CDA and media and then search. Another review is based on authenticity data. At first, 31 related studies were downloaded with 15 studies are a concrete theoretical framework. Only studies put on CDA were appraised and 16 research studies were read comprehensively and the content was analyzed according to major theoretical frameworks. The appendix shows a summary of research studies according to authors, year of a journal, research objectives, methodology, sources of data and findings. Besides that, the major frameworks reviewed three major themes. Firstly, The framework is concerned with CDA' application that using Fairclough's analytical. The secondly and thirdly, themes application using from Van Dijk's and Wodak framework within this frame around ten years.

\section{RESULTS AND DISCUSSION}

Studies on political, power and discursivity ideologies in discourse have been explored as hidden so many word connotation and power behind all word in exposing the identity of a social leader. It is open that power is often connected with the act of controlling the contributions of the non-powerful in the society' participants that take a position between the powerholder and the powerless. Actually, the powerless people are refrained to comment or debate on political issues. It is seeming that ideology has a power to sightless noncritical discourse analysis in various ways. In addition, the positive in self-presentation or negative in other-presentation strategies were frequently engaged. The discriminatory group is exposed as the negative other-presentation by the group' dominance which possesses positive self-presentation. The analytical 
frameworks for each study are indomitable by the researchers of the particular study. The studies further down are organized into three major themes which are related Van Dijk's and Fairclough's framework application.

\section{Van Dijk's framework application}

Nowadays, In media texts' approaches used mixed methods are very often working. Examples of mixed methods are the work of the Glasgow Media Group (1976, 1980, 1985) on news programs and Van Dijk's work (1998) comparing news reports in different countries. There are in content analysis combination with text-linguistic and analytical of discourse approaches. So far media are concerned in linguistic approaches with focusing mostly on the moment of the text. Although there has been increasing curiosity of viewers in the past years, studies that link media studies and response are still limited. Furthermore, Van Dijk has been noted in his studies about Ideological and social approaches.

\section{Ideological square}

Van Dijk's ideological framework: macrostrategies include negative other-presentation and positive self-presentation. The findings expressed various contradicting ideologies of the newspapers. One example media was posted against Iran is the phrase "a country which tries to advance a nuclear weapon". This phrase gives a horrifying ideology that seen as an intimidation. As a consequence, it is shown that prejudgment between the America-Iran associations as the most and less powerful ideology. Van Dijk's ideological square scanned the Islamic ideologies in the Egyptian newspaper. It is perceived that ideologies do emphasize the respectable and bad rules to expose. An instance that can be showed as negative is the presentation of unofficial Brotherhood relationship. The good statement "unofficial" as this clues to the understanding that "the Muslim Brotherhood" is not recognized as a group. Thus, events which are lead are said to be illegal and unauthorized. Hence, a negative belief is directed "the Muslim Brotherhood" to their good acts.
Another study, investigate the affiliation in each ideology and language in the manifestation of four main newspapers in America and Britain to scrutinize Islam's images. The newspaper' analysis headlines release the misconception, on how an issue is observed by the social life. An example which can be portrayed the headline "How Islam has been corrupted". This headline assumed Islam is corrupted. on the contrary,Islam stands do not like as they said. No corruption and No negative believes which cast an opposed bright upon the Muslim community.

Ahmadian and Farahani (2014) in the study of news reports was approved to consider the ideological differences in DA between The Los Angeles Times and Tehran Times under Van Dijk's ideological framework: macro-strategies which are the positive and negative presentation. The findings showed various

contradicting ideologies in both the newspapers were used in shoot upcountless negative ideologies against the others. Example one the phrase was posted, Iran is "a country which tries to develop a nuclear weapon". it gives a disturbing ideology to the society as a threat for them and it is open that prejudice looks like to be one of the main ideology between the America-Iran relationships as the most influential possesses a positive ideology meanwhile the less influential be a negative ideology.

\section{Social approach}

CDA aids discovering the unseen objectives by social actors insight of the society.Studied the bond discourse and ideology from political TV talk show are applicate to assists in finding out the hidden purposes from social actors in the perceptiveness of the society. Within this context, more than a few ideological can be spotted during the question and answer section when the politician missed and broke off sentences not wanting to show up certain questions raised by the journalist. In this context, several secret ideological stances can be realized. For example, it can be sawed during the question and answer session when the politician avoided and stopped smashed off sentences not requiring to show 
up certain questions mentioned by the anchor. This form of switching substances a lot as it could be a secret he did not want to reveal, or deliberately skipped off to another topic to redirect the attention of the audience. Therefore, it can be exemplified as emerged ideologies, the conversation is handled by the dominating one (politician) which collapsed the audience from additional inquiring. Discourse is comprehended to be dishonest to the pure as it hides ideological propositions which tends to be a stalker in the political subject. Azad (2013) in the news broadcasting that examined a negative ideological item was stared to the former president of United States, George Bush as his ' 8 years of the presidency' is stamped as ' 8 years of crime'. This stance implies to an unkind meaning as in an awful leader, an embarrassed occupant, and an authoritative.

In this application, it is also explored the company of ideology in a selection of radio news that implicit power is exercised. It is like President Obasanjo has recognized good governance in the certain news. His speech brought a faith that Nigeria's lack of good governance which has caused complications in the country's economy. For that reason, the existence President Obasanjo as the recent President is seen as a panacea to the country which will cure the unbalanced economic metropolitan. Thus, it implies a positive selfpresentation as the President is a person who conveys variations in the economic activities.

\section{Fairclough's framework application}

In the area of applied linguistics, CDA has been used colossally in various types analyzingthe critical phenomena which leads to the rise of a certain ideology, powerdomination and relationwithin a dominion, dissimilarity amonggenders, races, and social classes. It issupposed that the most fundamental aspect where domination and power are functional is in the lifeof the public over media. Media is a categorical public area is showing to variousideologies which outcome and blindfold their mind as a convinced ideology is required onthem in their daily life.For example, Zhang (2014) observed the news reports from political area among the context of American and Iraq in the American Newspapers specifically The NewYork Times employing Fairclough's three-dimensional framework to examine the discursivityof text, interactions, and perspective in unmasking the contradictory ideologies. Results have shown apositive ideology for the Bush government as he was ordered as a liberatorwhile the Iraqi community leader Sadam Hussein was written off as an enemy which exposed anegative ideology.

Further analysis opens a may partial image on both the countries thusportraying diverse ideological notions. Another study by Mayasari, Darmayanti, and Riyanto(2013) in the context of new reports marked at the take out the relationship between language aspect and ideology in the Indonesia Daily Newspapers on the formation of theCorruption Eradication Commission (CEC) building. The commonplaces between both the gatherings, CEC and Government, have led to a positive ideological construction for the CEC as the publicheld to anti-corruption which heartened donations in order to create thebuilding. On the other hand, the Government strongly opposite the production of the new buildingwhich caused to a negative ideological appearance. Thus, the negative ideological creationtowards the Government has been made as members of the Government are assumed to becorrupted and are complicated by corruption.

Fairclough (1995) and Garrett and Bell (1998) delivered a general idea of the different text of discourse analysis approaches and their media studies application. The Approaches engaged within critical linguistics to put emphasis on the prominence of the context of social and area of historical and the interdiscursive element. Consequently, the claim is not to expose "hidden meanings," as this would infer a static origin of the text, but to identify and analyze discursive outlines, argumentation, and revenues of awareness. Bell (1984)as an example, while seeing the microlinguistic advanced in viewers intention, considers the groups in word endings. CDA has been used colossally in various genres in 
applied linguistics such as certain ideology, power domination, discrimination among races, genders, and social classes. Where power and also authority is implemented is in the life of the public through media. Media' public is exposed to various ideologies which effect mind as a convinced ideology in our daily life.

Fowler (1991) put on several tools of linguistics functional includes the modality, transitivity, nominalizations, procedure of passives etc. In language studies of a rule of news on media. It means that analysis on media is anxious with a problem and not unbendingly simultaneous to the one or other linguistic methodology. What seems suitable is an approach of multimethod that syndicates different tools and levels of critical analysis.For illustration, Zhang (2014) studied the political news reports between the circumstance of American and Iraq in the American Newspapers in detail The New York Times exploiting three-dimensional framework of Fairclough investigated the discursivity of text, interactions, and context in finding the different ideologies. Results out a positive ideology for the Bush paperwork as he was classified as friendly and a liberator while Iraq'leader Sadam Hussein as an enemy which give negative ideology. Further analysis revealed a partial image on both the countries thus representing various ideological notions.

Vahid and Esmae'li (2012) studied the thoughts and power of companies' product through advertisements which inclined buyers indirectly. It is passed to enable consumers to trust the product totally. An example beauty product by Nivea exposing the word 'Goodbye Cellulite'. The ideology here is the product has the supremacy to go form any cellulite, and that it is truthful. It is interest for women with cellulite problems as these arguments are proficient of changing one's thoughts. In consequence, it is handled consumers strongly. In another opinion, Kaur, Arumugam, and Yunus (2013) also see the sights of ideology in the beauty products' advertisement. Discourse on the beauty products also as social practice on the text language and it grows into a portion of social practice. in the advertisements' language reveals a women's ideology and social status; as a result, women with fair skin, slim and good-looking more power than the ordinary women in the society. Through women' qualities is created exposing the duplicate of being 'in-group' rather than being oldfashioned. Phrases which are used to expose the sense of fashion are 'Big is Beautiful', 'Plump Your Lips', and 'Shimmering Rouge' which are linked with women of higher class.

Further, Mayasari, Darmayanti, and Riyanto (2013) also mentioned in their study in the case of new rumors about the liaison between some pieces of linguistic and philosophy in the Indonesia Daily Newspapers based on formation building of the Corruption Eradication Commission (CEC). They have been able to be a positive philosophical in public supported anti-corruption which stimulated donations in order to construct the building. Nonetheless, the Parliament strongly opposite the new building which resulted in a negative ideological image. Therefore, its assembly has been twisted as members of the Parliament are believed it to be corruption.

Another example delivered by Iqbal, Danish, and Tahir (2014a) also look at discourse used countless beauty products to capture women' mind in transmitting positively ideological but most consumers failed to notice the negativity in arrears discourse structure. For example, Popular product as a cream form like Fair \& Lovely uses words such as 'night fairness', 'face polish', and 'daily fairness'. In these words, women hug the belief that fairness. In consequence, the ideology manipulates women while handover negative views.

Besides products, another analysis is given by Fauzan, Subroto, and Poedjosoedarmo (2014) examined the unseen ideology in the Indonesian TV news reports. It discussed extra disaster of the mudflow. One may be unacquainted of the cause of mudflow, but the power of discourse dishonesties with the text maker. In this condition, he practiced to illuminating the ideologies. To help viewers gather mudflow caused by a) mudflow was not a natural tragedy; b) the effect of mudflow destroyed lives of many citizens; c) caused economic declination. These negative 
ideologies "underlined their bad things" (Van Dijk, 2000, p.44). In similarly, Tahmasbi and Kalkhajeh (2013) analyzed TV bank and magazine advertisements are expressed to endorse facility and to offer viewers in the banking sector. They have a target of watchers over discourse such as "Besides 201 offers to buy Peugeots 407". In this phrase, bank advertisers take on their viewers to purchasing or upgrading their car. Thus, the advertisers have created discourse which has manipulated the viewers indirectly.

In a related study, Behnam and Mahmoudy (2013) learned the political ideology in Iran's nuclear report. In determining the ideological structures. It can be described: "Iran has not providing requested information..." (Kerr, 2009, p.2). The phrase denotes a negative belief in Iran. Besides, it can be through monotonous words for instance contamination, undeclared, uncertainties, inconsistencies. It shows a negative image for such as a) Iran is trying to hide information from world' sight, and b) Iran is changeable in its nuclear program. Like to the studies above, Bolte and Keong (2014) analyzed $\mathrm{CDA}$ as the ideological representation of illegal immigrants in the Malaysia news that outlines the manner a text is made (Jorgenson \& Phillips, 2002; Fairclough, 1992) and vice-versa. It was found in the media discourse is the tools to protect of agreement that denotes a positive representation of Malaysia and Australia. Although, they were joined forces to provide accommodation to these immigrants.

\section{CONCLUSION}

This study is showing that mass media act a momentous role in the production of beliefs, prejudice, and power on social context. This study has established that CDA has popular in the arena of discourse studies by a look at the increasing quantity of CDA studies in investigating various social context to see the sights as well as correlation among language and ideology.This study have seen how discourse approach in social context examine the interaction patterns between participants, social goals and types of social events hence theemploy of the discursive practice in the relationship between text and social practice is bridged. Then, under the ideology context of elite which controls the thought of a social group it will then represent the basic social characteristics e.g identities, goals, norms, values, positions, and resources. This research used to observe how dominating group, elite (social actor e.g politician, public figure, wealth figure, religious figure) repress the less powerful person or minority. This study have found out that power often associated with the act of controlling and constraining the contributions of the nonpowerful participants in the society as this encounter usually takes place between the powerholder and the powerlessare refrained from commenting or debating on political issues and the rationality of an event. On the whole as there is implicit association in every word and power behind each word in unmasking the identity of a noble or horrendous character of the elite. It is unmistakable that CDA is a controlling tool in analyzing texts as ideological representations. Hence, this study review presented CDA which are marked to make recognized stereotypes, beliefs, domination, power and ideological relevance. In conclusion, the social circumstance defines the making of discourse and contributing the social power. Finally, the exploration of this research is hoped that $\mathrm{CDA}$ researchers can contribute existing CDA knowledge to elevation attentiveness for new researchers in conducting studies on Critical Discourse Analysis Studies.

\section{REFERENCES}

Ahmadian, M., \& Farahani, E. (2014). A critical discourse analysis of the los angeles times and tehran times on the representation of Iran's nuclear program. Theory and Practice in Language Studies, 4(10), 2114-2122.

Azad, O. (2013). Critical discourse analysis of 20: 30 news broadcasting. Modern Journal of LanguageTeaching Methods, 3(2), 78.

Behnam, B., \& Mahmoudy, B. (2013). A critical discourse analysis of the reports issued by the International Atomic Energy Agency (IAEA) Director General on Iran's nuclear program during the last decade. Theory and Practice in Language Studies, 3(12), 2196-2201. 
Bolte, S. \& Keong, Y. C. (2014). The refugee swap deal in malaysian online news reports: Ideology and representation. GEMA Online of Language Studies, 14(2), 93-108. http://dx.doi.org/10.17576/GEMA-2014-1402-07

Fairclough, N. (1992). Discourse and social change (Vol. 73). Cambridge: Polity Press.

Fairclough N (1995). Critical discourse analysis: The critical study of language. London: Longman.

Fairclough, N. (2009). A dialectical-relational approach to critical discourse analysis in social research. In Fowler, R. (1991). Critical linguistics. In K. Halmkjaer (Eds.), The linguistic encyclopedia (pp. 89-93). London: Routledge.

Fauzan, U., Subroto, H. E., \& Poedjosoedarmo, S. (2014). A CDA of the ideology of Indonesian metro tv news report. International Journal of Linguistics, 6(4), 71-86.

Hamuddin, B. (2012). A comparative study on politeness strategies in economic text. Master thesis. Kuala Lumpur: University of Malaya.

Hamuddin, B. (2015). Discourse on media: Bringing hot news into ELT's classroom discussion. Pekanbaru: Lancang Kuning University.

Hamuddin, B. (2016). Job vacancy discourse: Seeking an opportunity for English department alumni in newspapers. Jurnal Ilmu Komunikasi (JIK), 14(2).

Iqbal, A., Danish, M. H., \& Tahir, M. R. (2014a). Exploitation of women in beauty products of fair and lovely: A critical discourse analysis study. International Journal of Studies in English Language andLiterature, 2(9), 122-131.

Jorgensen, M. W., \& Phillips, L. J. (2002). Discourse analysis as theory and method. London: Sage.

Kaur, K., Arumugam, N., \& Yunus, N. M. (2013). Beauty product advertisements: A critical discourse analysis. Asian Social Science, 9(3), 6171.

Kerr, P. K. (2009). Iran's nuclear program: Tehran compliance with international obligations. USA: DIANE Publishing.

Mayasari, M., Darmayanti, N., \& Riyanto, S. (2013). Critical discourse analysis of reporting on "Saweran for KPK building" in media Indonesia daily newspaper. International Journal of Linguistics, 5(4), 213-224.
Reisigl, M., \& Wodak, R. (2009). The discoursehistorical approach (DHA). In R. Wodak, \& M. Meyer (Eds.), Methods of critical discourse analysis (pp 87-121). Thousand Oaks: Sage.

Tahmasbi, S., \& Kalkhajeh, S. G. (2013). Critical discourse analysis: Iranian banks advertisements. Asian Economic and Financial Review, 3(1), 124145.

Vahid, H., \& Esmae'li, S. (2012). The power behind images: Advertisement discourse in focus. International Journal of Linguistics, 4(4), 36-51.

Van Dijk, T. A. (1987). Episodic models in discourse processing. In R. Horowitz \& S.J. Samuels, (Eds.), Comprehensive oral and written language (pp.161-196). New York: Academic Press.

Van Dijk, T. A. (1990). Discourse \& society: A new journal for a new research focus. London: Sage Social Collection.

Van Dijk, T. A. (1995). Discourse analysis as ideology analysis. Language and Peace, 10, 47-142.

Van Dijk, T. A. (1998). Ideology: A multidisciplinary study. London: Sage.

Van Dijk, T. A. (2000). Ideology and discourse: A multidisciplinary introduction. Barcelona.

Van Dijk, T. A. (2001). Critical discourse analysis. In D. Schiffrin, D. Tannen, \& H. Hamilton (Eds.), (pp. 352-371).

Van Dijk, T. A. (2003). 18 Critical discourse analysis. In D. Tannen, D. Schiffrin, \& H. Hamilton (Eds.), Handbook of discourse analysis (pp. 352-371). Oxford: Blackwell.

Van Dijk, T. A. (2009). Critical discourse studies: A sociocognitive approach. Methods of Critical Discourse Analysis, 2(1), 62-86.

Wodak, R., \& Meyer, M. (2009). Critical discourse studies: A sociocognitive approach. In R. Wodak, \& M. Meyer (Eds.), Methods of critical discourse analysis (pp 162-187). Thousand Oaks: Sage.

Wodak, R., \& Busch, B. (2004). Approaches to media texts. In J. Downing (Eds.), Handbook of media studies. London: Sage.

Zhang, M. (2014). A critical discourse analysis of political news reports. Theory and Practice in Language Studies, 4(11), 2273-2277. 